\title{
The Changes of Soil Seed Banks In Time Series Before And After The Invasive Artemisia Trifida Was Removed From Grassland
}

\author{
Hanyue Wang ( $\sim 1483593889 @ q q . c o m$ ) \\ Shihezi University \\ Tong Liu \\ Shihezi University \\ Hegan Dong \\ Shihezi University \\ Wenxuan Zhao \\ Shihezi University \\ Xuelian Liu \\ Shihezi University \\ Ruili Wang \\ Shihezi University \\ Wenbin Xu \\ Shihezi University
}

\section{Research Article}

Keywords: Artemisia trifida, biological invasions, seed bank, restoration, grassland

Posted Date: May 28th, 2021

DOl: https://doi.org/10.21203/rs.3.rs-504715/v1

License: (c) (i) This work is licensed under a Creative Commons Attribution 4.0 International License.

Read Full License 


\section{$\mathrm{Xu}$}

\section{The changes of soil seed banks in time series before and after the}

\section{invasive Artemisia trifida was removed from grassland}

Hanyue Wang $\cdot$ Tong Liu $\cdot$ Hegan Dong $\cdot$ Wenxuan Zhao $\cdot$ Xuelian Liu $\cdot$ Ruili Wang $\cdot$ Wenbin

H. Wang, T. Liu ( $\bowtie)$, H. Dong, W Zhao, X Liu, R. Wang, W Xu

Xinjiang Production and Construction Corps Key Laboratory of Oasis Town and Mountain-basin System Ecology, Shihezi, China; College of Life Science, Shihezi University, Shihezi, China

E-mail: 469004509@qq.com

Abstract Artemisia trifida (giant ragweed) is an invasive weed with an expanding distribution area. In recent years it has been found to invade grasslands, bringing great challenges for effective weed control and restoration of native herbage. Although it has been reported that plant invasion can cause a decline in species richness and biodiversity in native seed banks, which may eventually lead to the depletion of native seed banks, few location- and species-specific case studies have been conducted regarding the dynamic characteristics of the invaded seed banks from invasion back to restoration. The purpose of this study was to compare and quantify the seed banks of grassland communities after (1) giant ragweed invasion for 0-8 years, and (2) giant ragweed removal, in Yili Valley, Xinjiang, China. The results showed that the duration of invasion determined whether giant ragweed could pose a significant threat to the native community seed bank. The seed bank density of native community had significantly decreased by $30.44 \%$ after 4 years of invasion, and in the sixth year, the species richness in the seed bank had decreased significantly by $12.36 \%$. After the invasion had lasted for eight years, the seed bank density of the native community had decreased by $83.28 \%$, the species richness in the seed bank decreased by $39.33 \%$, and the seed bank tended to be homogeneous. After the giant ragweed was removed, the potential for restoration was limited by the residual seed bank. Three years after the restoration, although the density of seed banks increased significantly, new growth was dominated by weedy species, rather than crucial components of the grassland habitat. This study is of great significance to the control of giant ragweed and the restoration of grassland vegetation invaded by giant ragweed.

Keywords: Artemisia trifida, biological invasions, seed bank, restoration, grassland

\section{Declarations}

Funding

The National Natural Science Foundation of China (31770461); The Natural Science Foundation of Xinjiang Province (2019D01B50); The Science and Technology Cooperation Project of Agricultural Resources and Environmental Protection Station of Xinjiang Uygur Autonomous Region.

\section{Conflicts of interest/Competing interests}

There are no financial, personal interests or beliefs that might affect the objectivity of the results of this study, and no potential conflicts of interest. To the best of our knowledge, the named authors have no conflict of interest, financial or otherwise. And all authors have declare that: (i) no support, financial or otherwise, has been received from any organization that may have an interest in the 
submitted work; and (ii) there are no other relationships or activities that could appear to have

43 influenced the submitted work.

\section{$44 \quad$ Availability of data and material}

45 Data for this study should be obtained by contacting the corresponding author.

46 Code availability

47 Not applicable.

\section{Authors' contributions}

49 Hanyue Wang, Tong Liu developed the idea of the study, participated in its design and coordination 50 and helped to draft the manuscript. Hegan Dong, Ruili Wang,Wenxuan Zhao, Xuelian Liu and Wenbin

$51 \mathrm{Xu}$ contributed to the acquisition and interpretation of data. All authors read and approved the final 52 manuscript.

53 Ethics approval

54 Not applicable.

55 Consent to participate

56 Not applicable.

57 Consent for publication

58 Not applicable. 


\section{Introduction}

Non-native invasive plant species are now recognized a major threat to ecosystems worldwide (Ehrenfeld 2010; Vilà and Hulme 2017). By virtue of their unique survival advantages, they can overpower local biodiversity and even exterminate entire species (Vila` et al. 2011; Pysek et al. 2012; Gilbert and Levine 2013). For many invasive spermatophytes, soil seed banks enhance the ability to maintain population growth and cause ecological damage (Gioria and Pysek 2016; Skálová et al. 2019), especially in annual plants that produce many seeds (Milakovic and Karrer 2016; Goplen et al. 2017; Chahal et al. 2018). This has created challenges for the control of invasive plants and to native vegetation restoration.

The germination of mature seeds may be delayed for an indefinite period. During this time, the seeds on the surface of or within the soil are likely to form a reserve, known as a soil seed bank (Fenner and Thompson 2005). The seeds of these reserves can be used for risk diversification, such as hedging risk with the germination strategy of long bets (Gremer and Venable 2014), and it is also helpful in maintaining the genetic and trait diversity of the population (Cabin et al. 2000; Mandak et al. 2012). In particular, many invasive annual spermatophytes, such as Ambrosia artemisiifolia (Dickerson and Sweet, 1971), Carrichtera annua (Cooke et al. 2012), and Amaranthus palmeri (Chahal et al. 2018), can produce a large number of seeds by the end of the growing season, so they are more likely to form an effective seed bank in a short time, accelerating the establishment and expansion of the population.

These characteristics that are advantageous to invasive plants allow them to fundamentally change the native plant community structure (Mason et al. 2007; Gioria and Osborne 2010). Previous studies have mainly focused on the changes in aboveground vegetation, exploring the impact of invasive plants on native plant communities; however, more and more attention has been paid recently to the relationship between invasive plants and local soil seed banks (Gioria and Osborne 2010; Gioria and PyEk 2016), as normal vegetation regeneration depends on the seeds in the soil. Studies have shown that invasive plants can produce higher density and more persistent seed banks in the newly invaded area (Gioria et al. 2019); they can reduce the density of the native community seed banks (Gioria and Osborne 2009), eventually destroying the community structure and reducing plant diversity (Gioria and Osborne 2010; Robertson and Hickman 2012; Dairell and Fidelis 2020). Moreover, research also shows that the resistance of the communities that have been invaded over long time periods is reduced due to the decline in diversity, so, these communities are easily invaded by other species (Marchante et al. 2011). Restoration of community species diversity has become among the main goals in ecology (Klaus et al. 2018; Dairel and Fidelis 2020), but it faces many difficulties (Maclean et al. 2018a; Nsikani et al. 2020). Despite the previously mentioned research, there are few case studies analysing site- and species-specific progression from seed bank to established invasion and back to native vegetation through restoration. Such studies can clarify whether vegetation degradation is caused by plant invasion or other reasons, and can identify the characteristics of seed bank changes in the early stage of the community after the removal of invasive plants, which is of great significance to the restoration (Gioria et al. 2014, 2016; Maclean et al. 2018b).

Giant ragweed (Ambrosia trifida L.) is an invasive annual weed native to North America, belonging to the genus Ambrosia (Compositae). Currently, it is distributed worldwide (Montagnani et al. 2017; www.gbif.org), where it poses a threat to natural ecosystems, agricultural production, and human health (Page and Nurse 2015; Regnier et al. 2016; Schaffner et al. 2020). Giant ragweed 
mainly invades wasteland, roadside, and riverside habitats, as well as important production farmlands (Gudžinskas 1993; Follak et al. 2013; Chauvel et al. 2015). Currently, research on its control is mainly focused on the farmland habitat, where research has identified that it has developed glyphosate resistance due to the long-term and frequent use of herbicides (Vink et al. 2012; Van Horn and Moretti 2018).

A special phenomenon occurs when giant ragweed invades grasslands (Montagnani et al. 2017), which poses a great threat to forage yield (Dong et al. 2020). It was first discovered in the Yili Valley, Xinjiang, China in 2010, and its distribution area had expanded to 2150-fold its original size by 2016 (Dong et al. 2017). By 2020, this distribution area has expanded 3113-fold, reaching 37900 ha. After 4-5 years of invasion with no external control, a single dense stand had formed over the area with nearly $100 \%$ population coverage, leading to a seed bank with certain characteristics (Dong et al. 2020). However, the effect of giant ragweed on the native seed banks in the process of forming a high coverage population remains unclear. It is also unknown whether the seed banks of the native community have the potential to recover after giant ragweed removal.

In order to solve this problem, in this study, we compared the composition of seed banks (1) with different invasion years (8 consecutive years) and (2) at different times after the control (three consecutive years). This enabled us to (1) identify the effects of giant ragweed invasion years on the seed bank composition of native plant communities, and (2) explore the restoration characteristics of native plant communities after giant ragweed removal. Our findings provide guidance for control of giant ragweed invasion in grasslands and restoration of such grasslands.

\section{Methods}

\section{Study site}

The study area was located in the Yili Valley $\left(80^{\circ} 0942^{\prime}-84^{\circ} 5650^{\prime} \mathrm{E}, 42^{\circ} 1416^{\prime}-44^{\circ} 5330^{\prime} \mathrm{N}\right)$, west of Tianshan Mountain in Xinjiang, China, with an average annual temperature of $10.4^{\circ} \mathrm{C}$ and an average annual precipitation of $417.6 \mathrm{~mm}$, it is the wettest area in Xinjiang. Giant ragweed grows mostly in the grasslands of this region, a diverse grazing area with rich chestnut soil, regarded as the source of the 'Chinese wild fruit gene pool'. Large distribution areas and high densities of giant ragweed pose a serious threat to native seedling regeneration (Dong et al. 2020).

The selected experimental plots were several connected pastures in pastoral areas where two kinds of gramineous plants, Festuca elata and Lolium perenne, are dominant, with Plantaginaceae, Leguminosae, Apiaceae, and Asteraceae species distributed among them (see Table 1 for details). We identified the invaded and noninvaded areas based on the morphological characteristics of individuals and populations of giant ragweed: tall plants, 2-4 $\mathrm{m}$ in adult height, formed aggregation patches in the invaded areas. Some sections were selected as long-term fixed plots for the experimental study. Because of the rapid diffusion ability of giant ragweed, it formed many populations with different invasion years, and some sections were selected as long-term fixed plots for the experimental study.

Fig. 1 Study area within Yili Valley, Xinjiang, China

\section{Experiment 1: variation characteristics of invaded seed banks with time series}

In order to test the influence of giant ragweed with different invasion years on the composition of native seed banks, we collected seed bank data from November 2018 (non-growth period, before snowfall) to reflect the supplementation of aboveground plants to the seed bank. 
A total of 480 soil samples were collected from seven sites that had been invaded by giant ragweed for 2-8 years, and the data that invaded by giant ragweed for 1 year were obtained around the site that invaded for 2 years, and also include the data of the native non-invaded areas. Each site contained multiple "patch communities" formed by the invasion of giant ragweed, and that 3 patch communities were tested at each site. Referring to the sampling methods of Robertson (2012) and Ferreras (2015), we randomly set up four $5 \times 5 \mathrm{~m}$ plots in each invasive community (in the middle of the invasive community, the edge area was avoided, because the edge may be newly established). The relative coverage of giant ragweed was estimated at the growth peak of mid-August. In the first ten days of November after the end of the growing season, four sampling points were selected from each plot, measuring $20 \times 20 \mathrm{~cm}, 5 \mathrm{~cm}$ deep (referring to Dong (2020), as our previous research showed that most of the seeds of giant ragweed gathered at 0-5 cm depth, and Robertson (2012), Dairel (2020) referred that the seeds of grassland herbs were mostly on the surface of soil). Soil was collected, and the four soil sampling points of each plot were mixed separately. The seed bank data of the native non-invaded areas were obtained from around the sites that had been invaded for 1, 3 and 7 years (the data obtained from the site of one year of invasion can be directly used here, because it had just settled here and had not caused harm to the native species and had not spread more seeds into the soil.), where three $20 \times 20 \mathrm{~m}$ plots were set in the noninvaded areas and four $5 \times 5 \mathrm{~m}$ quadrats were randomly set in each plot. The sampling method was the same as above.

For identification and quantification of soil seeds before the collection of soil seed bank samples, all types of spermatophytes on the ground were investigated and recorded, and some seeds were collected during the seed setting period to compare and identify the species in the seed banks. After the soil samples were dried and crushed, the plants and large particles were removed, and the seeds were obtained using meshes with different pore sizes. Smaller seeds were identified using a magnifying glass. The characteristics of the seeds taken from the plants were compared, and all separated seeds were counted.

Experiment 2: Restoration characteristics of native seed banks after removing invasive plants in time series

In order to explore the self-recovery potential of the native community after the removal of invasive species, we carried out the control of giant ragweed, and continuously monitored the dynamics of seed banks for three years.

In June 2018, an invaded community (one of the communities selected in Experiment 1) was selected at the site with 8 years of invasion, and four $5 \times 5 \mathrm{~m}$ plots were set (located near the selected sample in Experiment 1). At the same time, all plants $1 \mathrm{~m}$ around each plot were cleared, and each plot was fenced with barbed wire to prevent cattle, sheep, and other animals from entering.

We used herbicides for controlling broad-leaved weeds in late June, when the giant ragweed was about $1 \mathrm{~m}-1.2 \mathrm{~m}$ high, in the vegetative growth stage, and its leaves and stems were sprayed. Spraying treatments were carried out for two years, in 2018 and 2019 (when the first spraying was carried out in 2018, the aboveground portion was all giant ragweed, so herbicide was applied indiscriminately in the canopy; in the second year, the spraying was only carried out in the places where giant ragweed grew, so as to avoid damage to other broad-leaved grasses). The seed bank data were collected in these two years and in November 2020, using the same collection method as in Experiment 1. Each sampling point was marked for organizational purposes. The seeds of all species were separated and determined, and the continuous changes in seed bank composition after spraying were compared. The change in canopy coverage of community components (giant ragweed, native plants, blank patch) was 
estimated with an increase in restoration time.

\section{Data analysis}

All data are represented as mean $\pm \mathrm{SE}$, and data analysis was conducted in Excel 2019 and in SPSS 2019. In order to confirm that degradation was caused by giant ragweed invasion, and not by other causes, we selected three of the eight sites (representing 1-8 years of invasion, respectively) in the study area and sampled the noninvaded areas around them. These areas were used to represent the species richness and seed bank density before the invasion. The data distribution characteristics were expressed by a box chart. If the two index values of the invaded area showed a regular decline with the increase in the invasion duration, and were lower than this range midway, then it could be determined that the invasion reduced the species richness and seed bank density. After seed separation, the seed bank density of each species per $1 \mathrm{~m}^{2}$ was calculated according to the area. Single factor analysis of variance (ANOVA) and multiple comparisons of least significant difference (LSD) were used to compare (1) the change in seed bank density of native communities, and (2) the change in species composition and richness under different invasion years and different restoration years. When the data did not conform to homogeneity of variance, Welch's ANOVA method was used for analysis. 

plant community

Through the identification of the noninvaded seed banks, 32 species belonging to 17 families were identified (Table 1). We calculated the distribution frequency and estimated the average plant height.of each species.

213 Table 1 Species and their characteristics in noninvaded area

\begin{tabular}{|c|c|c|c|c|}
\hline Families & Species & Life cycle & Plant height $(\mathrm{cm})$ & Frequency \\
\hline \multirow[t]{7}{*}{ Gramineae } & Festuca elata & perennial & 110 & $100.00 \%$ \\
\hline & Lolium perenne & perennial & 95 & $95.83 \%$ \\
\hline & Agrostis matsumurae & perennial & 60 & $54.17 \%$ \\
\hline & Bromus japonicus & annual & 55 & $79.17 \%$ \\
\hline & Eleusine indica & annual & 4 & $75.00 \%$ \\
\hline & Setaria viridis & annual & 25 & $58.33 \%$ \\
\hline & Eragrostis pilosa & annual & 25 & $41.67 \%$ \\
\hline \multirow[t]{7}{*}{ Asteraceae } & Achillea millefolium & perennial & 35 & $50.00 \%$ \\
\hline & Cirsium setosum & perennial & 115 & $66.67 \%$ \\
\hline & Taraxacum mongolicum & perennial & 15 & $62.50 \%$ \\
\hline & Cichorium intybus & perennial & 85 & $83.33 \%$ \\
\hline & Arctium lappa & biennial & 20 & $83.33 \%$ \\
\hline & Conyza Canadensis & annual & 50 & $58.33 \%$ \\
\hline & Sonchus oleraceus & annual & 40 & $83.33 \%$ \\
\hline \multirow[t]{3}{*}{ Leguminosae } & Sophora alopecuroides & perennial & 50 & $50.00 \%$ \\
\hline & Trifolium pratense & perennial & 15 & $83.33 \%$ \\
\hline & Medicago sativa & perennial & 20 & $83.33 \%$ \\
\hline \multirow[t]{2}{*}{ Chenopodiaceae } & Atriplex horuensi & annual & 55 & $66.67 \%$ \\
\hline & Chenopodium album & annual & 70 & $45.83 \%$ \\
\hline Urticaceae & Urtica fissa & perennial & 145 & $83.33 \%$ \\
\hline Papilionaceae & Glycyrrhiza uralensis & perennial & 40 & $75.00 \%$ \\
\hline Ranunculaceae & Thalictrum aquilegifolium & perennial & 60 & $62.50 \%$ \\
\hline Rubiaceae & Galium spurium & perennial & 35 & $66.67 \%$ \\
\hline Rosaceae & Agrimonia pilosa & perennial & 65 & $41.67 \%$ \\
\hline Boraginaceae & Myosotis silvatica & perennial & 50 & $83.33 \%$ \\
\hline Apiaceae & Daucus carota & biennial & 125 & $79.17 \%$ \\
\hline Moraceae & Cannabis sativa & annual & 120 & $95.83 \%$ \\
\hline Plantaginaceae & Plantago depressa & perennial & 35 & $70.83 \%$ \\
\hline Amaranthaceae & Amaranthus retroflexus & annual & 30 & $66.67 \%$ \\
\hline Brassicaceae & Capsella bursa-pastoris & annual & 40 & $75.00 \%$ \\
\hline Labiatae & Salvia japonica & annual & 45 & $58.33 \%$ \\
\hline Balsaminaceae & Impatiens brachycentra & annual & 55 & $45.83 \%$ \\
\hline
\end{tabular}

The seed bank density in noninvaded area was between 21500 and 37800 seeds per $\mathrm{m}^{2}(\mathrm{~F}=2.775$, $P=0.077$; Fig. 2a) and the number of species was between 20 and 25 (F=0.377, $P=0.698$; Fig. 2b). On the ground, the relative coverage of giant ragweed continued to increase with the invasion time, 
reaching $83.75 \%( \pm 79 \%)$ in the fourth year, reaching $100 \%$ in the sixth year of invasion (Fig. 3a). The seed bank density of the native species community decreased with the increase of the invasion duration (Fig. $3 \mathrm{~b} ; \mathrm{R}^{2}=0.9336, \mathrm{p}<0.01$ ). There was no significant difference between the seed bank density of the community and that noninvaded area in the first three years of invasion, and the seed bank density decreased significantly by $30.44 \%$ from the fourth year (Fig. 3b). However, the seed bank density of the dominant species (Festuca elata and Lolium perenne) decreased significantly by $16.75 \%$ from the third year (Fig. 3d). The species richness in the seed banks began to decrease significantly by $12.36 \%$ in the sixth year, and then decreased year by year (Fig. 3c). In terms of species composition, the seed bank density of Gramineae and non-Gramineae decreased continuously with the increase of invasion duration (Fig. 3e); The seed bank density of species with different life cycles (perennial, biennial and annual) also showed a continuous downward trend (Fig. 3f).

Fig. 2 The distribution characteristics of (a) seed bank density and (b) species richness in noninvaded area are represented by box chart

Fig. 3 Effects of giant ragweed invasion duration on aboveground relative coverage and underground seed bank of native community. (a) the changes of relative coverage of giant ragweed with invasion time; the changes of (b) seed bank density and (c) species richness of native communities; and the changes of seed bank density with invasion time of (d) two dominant species and (e) gramineae/non-gramineae (f) and that species with different life cycles. Different letters indicate significant differences $(\mathrm{p}<0.05)$ using a least significant difference test

Chemical control can rapidly consume the soil seed bank and reduce the relative coverage of aboveground parts. During the vegetative growth period in June, giant ragweed stopped growing until withered. Most of the giant ragweed plants did not bear seeds or few seeds, which could not supplement the consumption of seed bank. Compared with the control, the soil seed bank decreased by $87 \%$ in first year; the seed bank of giant ragweed almost disappeared in the third year (Table 2).

Table 2 Effect of chemical control on giant ragweed

\begin{tabular}{ccc}
\hline Measuring time & Relative coverage & Seed bank density \\
\hline Before chemical control & $100 \% \mathrm{a}$ & $15045.31 \pm 2156.77 \mathrm{a}$ \\
In 2018 & $100 \% \mathrm{a}$ & $1975 \pm 494.21 \mathrm{~b}$ \\
In 2019 & $17.5 \% \pm 5 \% \mathrm{~b}$ & $310.94 \pm 83.76 \mathrm{bc}$ \\
In 2020 & $3.75 \% \pm 2.89 \% \mathrm{c}$ & $17.19 \pm 5.98 \mathrm{c}$ \\
\hline
\end{tabular}

Note: Different letters indicate significant differences $(\mathrm{p}<0.05)$ using a least significant difference test.

After chemical control, the relative seed bank density of giant ragweed decreased rapidly until it disappeared, accompanied by the rapid increase of seed bank density of native plants (Fig. 4a). In the third year of restoration, the density of seed bank had reached the same level as that of noninvaded area (Fig. 4a) and the coverage of native community had also been restored (Fig. 4c). However, the families that had disappeared in the duration of invasion could not be reestablished, and the species richness decreased by $41.57 \%$ compared with that before invasion (Fig. $4 \mathrm{~b}$ ).

The relative seed bank density of Compositae and Apiaceae increased 8.79 and 7.77 times compared with that before restoration, and 4.47 and 12.5 times compared with that before invasion. The relative seed bank density of biennial plants from $2.93 \% \pm 1.98 \%$ before invasion to $37.7 \% \pm 18.3 \%$ 
after restoration, increased by 12.87 times (Table 3).

Fig. 4 The restoration of (a) native seed bank density, (b) species richness in the seed bank and (c) native community coverage after removal of giant ragweed. Different acronyms represent different restoration times that NA (Noninvaded area), BR (Before restoration), FR (The first year of restoration), SR (The second year of restoration), TR (The third year of restoration). Different letters indicate significant differences $(\mathrm{p}<0.05)$ using a least significant difference test

Table 3 Changes of relative seed bank density (\%) of native plants in different families and life cycles during natural restoration

\begin{tabular}{|c|c|c|c|c|c|}
\hline Class & NA & $\mathrm{BR}$ & FR & SR & TR \\
\hline Gramineae & $60.19 \pm 13.97 \mathrm{ab}$ & $53.04 \pm 8.92 b$ & $54.88 \pm 25.95 b$ & $76.22 \pm 8.78 \mathrm{a}$ & $43.56 \pm 15.09 b$ \\
\hline Asteraceae & $2.44 \pm 1.47 \mathrm{~b}$ & $1.24 \pm 1.2 \mathrm{~b}$ & $2.52 \pm 0.41 \mathrm{~b}$ & $2.77 \pm 1.33 b$ & $10.9 \pm 7.76 \mathrm{a}$ \\
\hline Plantaginaceae & $24.33 \pm 17.44 \mathrm{ab}$ & $33.76 \pm 13.14 \mathrm{a}$ & $32.97 \pm 24.49 \mathrm{a}$ & $10.54 \pm 9.45 \mathrm{c}$ & $14.38 \pm 9.82 \mathrm{ab}$ \\
\hline Brassicaceae & $5.38 \pm 3.75$ & $5.23 \pm 4.26$ & $2.69 \pm 3.76$ & $0.59 \pm 0.74$ & $1.75 \pm 2.08$ \\
\hline Rubiaceae & $0.35 \pm 0.34$ & $0.22 \pm 0.19$ & / & / & l \\
\hline Apiaceae & $2.2 \pm 1.85 b$ & $3.54 \pm 2.57 \mathrm{~b}$ & $4.69 \pm 2.28 \mathrm{~b}$ & $5.47 \pm 2.68 b$ & $27.49 \pm 14.19 a$ \\
\hline Moraceae & $0.96 \pm 0.46 b$ & $0.87 \pm 0.38 \mathrm{~b}$ & $0.66 \pm 0.37 b$ & $1.99 \pm 0.25 \mathrm{a}$ & $1.03 \pm 0.31 \mathrm{~b}$ \\
\hline Amaranthaceae & $0.99 \pm 0.84$ & $1.52 \pm 0.91$ & $0.97 \pm 0.88$ & $1.43 \pm 1.06$ & $0.54 \pm 0.4$ \\
\hline Leguminosae & $0.5 \pm 0.58$ & $0.4 \pm 0.27$ & $0.25 \pm 0.13$ & $0.59 \pm 0.29$ & $0.22 \pm 0.13$ \\
\hline Rosaceae & $0.06 \pm 0.11$ & I & / & l & / \\
\hline Papilionaceae & $0.19 \pm 0.17$ & l & l & / & l \\
\hline Urticaceae & $0.86 \pm 0.53$ & l & / & l & / \\
\hline Boraginaceae & $0.87 \pm 0.81$ & l & I & l & l \\
\hline Balsaminaceae & $0.04 \pm 0.05$ & l & l & / & / \\
\hline Chenopodiaceae & $0.35 \pm 0.36$ & $0.07 \pm 0.17$ & $0.39 \pm 0.47$ & $0.41 \pm 0.51$ & $0.13 \pm 0.16$ \\
\hline Ranunculaceae & $0.13 \pm 0.15$ & I & / & / & / \\
\hline Labiatae & $0.16 \pm 0.39$ & / & / & / & 1 \\
\hline Perennial & $50.21 \pm 12.21 \mathrm{ab}$ & $44.68 \pm 5.87 \mathrm{bc}$ & $36.06 \pm 14.21 \mathrm{c}$ & $61.51 \pm 6.81 \mathrm{a}$ & $31.81 \pm 14.48 \mathrm{c}$ \\
\hline Annual & $46.85 \pm 13.14 \mathrm{a}$ & $50.98 \pm 6.6 \mathrm{a}$ & $57.59 \pm 15.01 \mathrm{a}$ & $31.08 \pm 7.4 b$ & $30.49 \pm 7.06 b$ \\
\hline Biennial & $2.93 \pm 1.98 \mathrm{~b}$ & $4.34 \pm 2.74 \mathrm{~b}$ & $6.35 \pm 1.22 \mathrm{~b}$ & $7.41 \pm 2.49 b$ & $37.7 \pm 18.3 \mathrm{a}$ \\
\hline
\end{tabular}

Note: Different letters indicate significant differences $(p<0.05)$ using a least significant difference test.

\section{Discussion}

1. The invasion duration of giant ragweed for 4 years can cause significant damage to the aboveground and underground parts of the grassland community.

We found that the duration of invasion was correlated to the ecological damage caused by giant ragweed. The seed bank density of the native community showed a downward trend from the fourth year of invasion and decreased by $83.28 \%$ after 8 years of invasion. For the dominant plants (Festuca elata and Lolium perenne) in the experimental area, the seed bank density began to decrease significantly in the third year. Over eight years, the seed bank density of the community decreased from 30057.85 seeds to 5025 seeds per $\mathrm{m}^{2}$, and the seed bank density of the dominant species decreased from 12888.28 seeds to 2153.12 seeds per $\mathrm{m}^{2}$, accounting for $42.88 \%$ of the decrease. The data of seed bank density of the community also showed that the difference of seed banks density became smaller with an increase in the duration of invasion, indicating that giant ragweed gradually 
occupied the dominant position in the community seed bank components, making the seed banks highly similar. The species richness of seed banks decreased significantly in the sixth year, and then it decreased significantly every year. In the eighth year, the average number of species from 22.5 dropped to 13.5 .

There is debate as to whether changes in the seed banks of native and alien species are a symptom of environmental degradation prior to plant invasion, or whether they are its direct result (Gioria et al. 2014); and plant invasion maybe not necessarily affect the species richness or density of native seed banks (Robertson and Hickman 2012). These are controversial issues. However, an increasing number of studies have shown that the seed bank of invasive plants is one of the important reasons for their successful invasion as many invasive plants can form seed banks with certain characteristics in new habitats (Strydom et al. 2017; Gioria et al. 2019) and the relative seed bank size of invasive plants in newly formed communities will increase with the duration of invasion (Dairel and Fidelis 2020), causing the species richness and density of invaded seed banks to decrease significantly. However, due to the lack of continuous observation data of target invasive plants from establishment to hazard, it is difficult to quantify the specific impact of different invasion durations on native seed banks. To solve this problem, we need to know the state of the community before it was invaded, and the continuous change of the invaded and uninvaded areas with time. However, there are only a few such cases.

We compared pre- and post-invasion data to examine the cause-effect nature of invasion. Our investigation of non-invaded areas revealed that 20-25 species in the original non-invaded communities, and the seed bank density in November was between and 21500-37800 seeds per $\mathrm{m}^{2}$. As seen in Figure[2], the two index values of the invaded area show a regular decline with the increase in the invasion duration and are lower than this range midway, indicating that the invasion reduced the species richness and seed bank density.

These results indicate that the duration of invasion is key to reducing the native species diversity of invasive plants. The data showed that the seed bank density of the original noninvaded communities were differences (30057.85 \pm 9393.64$)$. However, with the increase in invasion time, the seed bank density of the native communities decreased significantly and became more homogeneous. Eight years later, the seed bank density of giant ragweed reached $14796.88 \pm 98$ grains per $\mathrm{m}^{2}$, accounting for $74.63 \%$ of the new community.

\section{The control of invasive giant ragweed has higher technical requirements, but a rapid control effect can be achieved by restraining or reducing the input of giant ragweed plants into the soil seed bank.}

Records show that giant ragweed mainly grows near the river bank and equidistant from the water source, or on the edge of cultivated land (mainly corn, soybean, cotton fields) or on both sides of railway or wasteland (Gudzìnskas 1993; Follak et al. 2013; Chauvel et al. 2015; Emilie et al. 2016).

There are special requirements for the chemical control of giant ragweed invading grassland. Our survey found that the species richness of grassland was higher than that of farmland, roadside, wasteland, and other habitats, and as animal husbandry land, the requirements for safe drug use are more stringent. Therefore, it is necessary to develop special chemical control methods based on their growth and reproduction characteristics.

It is newly recorded that giant ragweed invades grassland and causes serious damage. Through previous studies (Dong et al. 2020) and this study, it was found that a large number of seeds are 
produced every year, which is an important reason why giant ragweed can cause damage to the grassland. With the increase in invasion years, a dense forest population was formed in the aboveground portion of the studied ecosystem. The relative coverage of the population expanded explosively in the fourth year, reaching $83.75 \%$, and reaching $100 \%$ by the sixth year (Fig. 3a). The plant height of giant ragweed invading grassland is generally 2-4 $\mathrm{m}$, which is higher than that of native plants (Table 1). Therefore, giant ragweed has more advantages in the competition for light resources. It can suppress the resources of other plants on the ground, so that native plants cannot effectively supplement native seed banks. From the second year of invasion, the relative seed bank density of giant ragweed reached $3.15 \%$, and then increased significantly every year, reaching $74.63 \%$ in the eighth year (Fig. 3e) and becoming the main component of underground soil seed banks. However, more than $98.66 \%$ of its seeds are consumed in one year, and a few of them are actually used for germination (Dong et al. 2020). Therefore, it can be said that the high seed bank density generated in that year is the basis for the formation of a dense population of giant ragweed in the following year.

As mentioned earlier, invasive spermatophytes can often produce a large number of seeds, which can easily form seed banks in invasive areas and increase their invasion potential (Passos et al. 2017; Nguyen et al. 2017; Maclean et al. 2018a; Gioria et al. 2019). Based on previous studies, it was found that the best control method for these invasive plants is to forbid produce seeds and consume the existing underground seed banks. For example, mowing or biological control of ragweed (Ambrosia artemisiifolia) in a specific period can reduce its seed yield and consume the seed bank (Basky et al. 2017; Lommen et al. 2018; Augustinus et al. 2020). In farmland, the control can be achieved by formulating a rotation system between different crops to inhibit the germination of giant ragweed seeds and consume its seed bank (Goplen et al. 2017). This study showed that the use of specific chemicals in the specific growth period of giant ragweed could inhibit seed production and rapidly consume its soil seed bank. The density of seed banks could be reduced by $86.87 \%$ in the year of application, and the soil seed bank and aboveground population almost disappeared in the third year (Table 2), so as to achieve effective weed control.

\section{The potential of natural restoration after removal of invasive plants is limited and the characteristics of seed bank restoration are species-specific.}

The first goal in prevention and control is to remove invasive plants from the community. Second is to ensure that the community can recover species diversity before re-invasion (Klaus et al. 2018; Dairel and Fidelis 2020). However, clearing invasive plants often facilitates secondary invasion and/or weedy native species dominance instead of native biodiversity recovery, and therefore, it has limited natural restoration potential (Nsikani et al. 2020; Maclean et al. 2018a, b).

The results showed that the original species diversity could not be restored in a short time after the invasive plants were removed from the community. Based on the empty niche hypothesis, other invasive plants or residual species may occupy the spaces left after giant ragweed removal (O'Loughlin and Green 2017; Maclean et al. 2018a). After the giant ragweed was removed, very few native species remaining in the seed banks quickly responded to the habitat changes, successfully re-established, and proliferated in large numbers in the community, occupying the blank patch. In the third year of restoration, a few native plant species had completely covered the blank niche left by the control (Fig. 4c), and the species that had disappeared before the control could not re-enter in a short time.

We found that the relative seed bank density of Compositae and Apiaceae was significantly 
higher than that of non-invaded area after 3 years of restoration in weed control area (Table 3), reaching 4.47-fold and 12.5-fold of non-invaded area, respectively. The relative seed bank density of biennial plants was 12.87 -fold higher than that of non-invaded areas. Biennial plants rapidly occupied the niche left by giant ragweed removal and produced a large number of seeds, while the seed bank of other plants either had no significant change in three years or had no regularity of change (Table 3 ). Biennial plants can germinate in autumn or before snowfall and overwinter as seedlings. At this time, the giant ragweed has ended its life cycle. In the second year, giant ragweed begins to germinate in large quantities during snow melting, and the number of seedlings exceeds 800 plants per $\mathrm{m}^{2}$, which is advantageous for germination time (Margherita et al. 2016), limiting the growth of other plants. Biennial plants, such as wild carrots belong to Umbelliferae, begin to grow rapidly at this time (April), and when giant ragweed is still in the vegetative growth stages (May to July), it has already begun to blossom and pollinate. When giant ragweed enters the flowering stage (July August), the biennial plants have already fruited and are about to end their life. Therefore, we speculate that this misplaced life cycle is an important reason for biennial plants could still survive in grasslands invaded by giant ragweed and get the advantage after giant ragweed removed.

In summary, short-term (8-year) invasion seriously damaged the structure of the grassland community. Different plant species exhibit different restoration characteristics. A community with less diversity, dominated by some native non-dominant plants (biennial plants) has been reconstructed after invasion. So we suggest that the restoration of diversity can be assisted by the addition of annual and perennial seeds at the same time as chemical control.

\section{Conclusions}

Our study showed that giant ragweed invasion not only threatened the aboveground part of the native community, as the relative coverage reached $100 \%$ in a short time (six years), but also gradually became the main component of the seed banks (the proportion of giant ragweed in the seed bank reached $74.63 \%$ after eight years). After eight years of continuous invasion, the native plants almost only existed in the seed banks, the species richness decreased by $39.33 \%$, the native seed bank density decreased by $83.28 \%$, and the seed banks tended to be homogenized. After removing the aboveground and underground giant ragweed, the restoration potential of the invaded community was very limited. Only some native species were re-established, the species diversity was almost unchanged, and only the abundance changed. Therefore, artificial sowing of seeds from native plants that are lacking at the same time as chemical control is necessary to restore plant diversity.

This study adds detailed time dimension information to the understanding of the impact of invasive plants on community seed banks so that we can clearly understand the changes in community seed bank composition during the process of invasive plants from establishment to hazard, as well as clarify the rapid changes in community seed bank composition after the removal of invasive plants. This information can be used to determine whether a community has potential for natural restoration, and plays an important role in the control of giant ragweed and the vegetation restoration of grasslands.

\section{Acknowledgements}

This project was funded by The National Natural Science Foundation of China (31770461), The Natural Science Foundation of Xinjiang Province (2019D01B50); and The Science and Technology Cooperation Project of Agricultural Resources and Environmental Protection Station of Xinjiang Uygur Autonomous Region. We would like to thank Editage (www.editage.cn) for English language editing. 


\section{References}

Augustinus BA, Lommen STE, Fogliatto S et al (2020) In-season leaf damage by a biocontro 1 agent explains reproductive output of an invasive plant species. Neobiota 55:117-146. ht tps://doi.org/10.3897/neobiota.55.46874

Basky Z, Ladányi M, Simončič A (2017) Efficient reduction of biomass, seed and season lon $\mathrm{g}$ pollen production of common ragweed (Ambrosia artemisiifolia L.). Urban For Urban Gree 24:134-140. https://doi.org/10.1016/j.ufug.2017.03.028

Cabin RJ, Marshall DL, Mitchell RJ (2000) The demographic role of soil seed banks. II. Inv estigations of the fate of experimental seeds of the desert mustard Lesquerella fendleri. J Ecol 88(2):293-302. https://doi.org/10.1046/j.1365-2745.2000.00444.x

Chahal PS, Irmak S, Jugulam M et al (2018) Evaluating effect of degree of water stress on growth and fecundity of Palmer amaranth (Amaranthus palmeri) using soil moisture senso rs. Weed Sci 66(6):738-745. https://doi.org/10.1017/wsc.2018.47

Chauvel B, Rodriguez A, Moreau C et al (2015) Développement d'Ambrosia trifida L. en Fra nce: connaissances historiques et écologiques en vue d'une éradication de l'espèce. Journ al de Botanique de la Société botanique de France 71:25-38

Cooke J, Ash JE, Groves RH (2013) Population dynamics of the invasive, annual species, $\mathrm{Ca}$ rrichtera annua, in Australia. The Rangeland Journal 34(4):375-387. https://doi.org/10.107 $\underline{1 / R J 12027}$

Dairel M, Fidelis A (2020) The presence of invasive grasses affects the soil seed bank comp osition and dynamics of both invaded and non-invaded areas of open savannas. J Enviro n Manage 276:111291. https://doi.org/10.1016/j.jenvman.2020.111291

Diagne C, Leroy B, Gozlan RE et al (2020) InvaCost, a public database of the economic cos ts of biological invasions worldwide. Sci Data 7(1):1-12. https://doi.org/10.1038/s41597-02 $\underline{0-00586-\mathrm{Z}}$

Dickerson Jr CT, Sweet RD (1971) Common ragweed ecotypes. Weed Sci 64-66

Dong H, Liu T, Liu Z et al (2020) Fate of the soil seed bank of giant ragweed and its sign ificance in preventing and controlling its invasion in grasslands. Ecol Evol 10(11):4854-4 866. https://doi.org/10.1002/ece3.6238

Dong HG, Zhou MD, Liu ZQ et al (2017) Diffusion and intrusion features of Ambrosia arte misiifolia and Ambrosia trifida in Yili River Valley. Journal of Arid Land Resources \& Environment 31(11):175-180

Ehrenfeld JG (2010) Ecosystem consequences of biological invasions. Annu Rev Ecol Evol S 41:59-80. https://doi.org/10.1146/annurev-ecolsys-102209-144650

Emilie E, Regnier et al (2016) Certified Crop Advisors' Perceptions of Giant Ragweed (Ambr osia trifida) Distribution, Herbicide Resistance, and Management in the Corn Belt. Weed Sci 64(2):361-377. https://doi.org/10.1614/WS-D-15-00116.1

Fenner M, Thompson K (2005) The Ecology of Seeds; Cambridge University Press: Cambrid ge, UK.

Ferreras AE, Giorgis MA, Tecco PA et al (2015) Impact of Ligustrum lucidum on the soil se ed bank in invaded subtropical seasonally dry woodlands (Córdoba, Argentina). Biol Inva sions 17(12):3547-3561. https://doi.org/10.1007/s10530-015-0977-1

Follak S, Dullinger S, Kleinbauer I et al (2013) Invasion dynamics of three allergenic invasiv e Asteraceae (Ambrosia trifida, Artemisia annua, Iva xanthiifolia) in central and eastern 
Europe. Preslia 85(1):41-61. https://doi.org/doi:10.1093/jxb/ers398

Gilbert B, Levine JM (2013) Plant invasions and extinction debts. P Natl Acad Sci USA 110 (5):1744-1749. https://doi.org/10.1073/pnas.1212375110

Gioria M, Jarošík V, Pyšek P (2014) Impact of invasions by alien plants on soil seed bank c ommunities: emerging patterns. Perspect Plant Ecol 16(3):132-142. https://doi.org/10.1016/j. ppees.2014.03.003

Gioria M, Le Roux JJ, Hirsch H et al (2019) Characteristics of the soil seed bank of invasiv e and non-invasive plants in their native and alien distribution range. Biol Invasions 21 (7):2313-2332. https://doi.org/10.1007/s10530-019-01978-y

Gioria M, Osborne B (2009) Assessing the impact of plant invasions on soil seed bank com munities: use of univariate and multivariate statistical approaches. J Veg Sci 20(3):547-55 6. https://doi.org/10.1111/j.1654-1103.2009.01054.x

Gioria M, Osborne B (2010) Similarities in the impact of three large invasive plant species o $\mathrm{n}$ soil seed bank communities. Biol Invasions 12(6):1671-1683. https://doi.org/10.1007/s10 530-009-9580-7

Gioria M, Pyšek P (2016) The legacy of plant invasions: changes in the soil seed bank of in vaded plant communities. BioScience 66(1):40-53. https://doi.org/10.1093/biosci/biv165

Goplen JJ, Sheaffer CC, Becker RL et al (2017) Seedbank depletion and emergence patterns of giant ragweed (Ambrosia trifida) in Minnesota cropping systems. Weed Sci 65(1):52-6 0. https://doi.org/10.1614/WS-D-16-00084.1

Gremer JR, Venable DL (2014) Bet hedging in desert winter annual plants: optimal germinati on strategies in a variable environment. Ecol Lett 17(3):380-387. https://doi.org/10.1111/el e.12241

Gudžinskas Z (1993) Genus Ambrosia L.(Asteraceae) in Lithuania. Thaiszia Journal of Botany 3(1):89-96

Klaus VH, Hoever CJ, Fischer M et al (2018) Contribution of the soil seed bank to the rest oration of temperate grasslands by mechanical sward disturbance. Restor Ecol 26:S114-S1 22. https://doi.org/10.1111/rec.12626

Lommen STE, Jongejans E, Leitsch-Vitalos M et al (2018) Time to cut: population models re veal how to mow invasive common ragweed cost-effectively. NeoBiota 39(39):53-78. http s://doi.org/10.3897/neobiota.39.23398

Maclean JE, Mitchell RJ, Burslem DFRP et al (2018a) Invasion by Rhododendron ponticum d epletes the native seed bank with long-term impacts after its removal. Biol Invasions 20 (2):375-384. https://doi.org/10.1007/s10530-017-1538-6

Maclean JE, Mitchell RJ, Burslem DFRP et al (2018b) Understorey plant community composi tion reflects invasion history decades after invasive Rhododendron has been removed. J Appl Ecol 55(2):874-884. https://doi.org/10.1111/1365-2664.12973

Mandak B, Zákravský P, Mahelka V et al (2012) Can soil seed banks serve as genetic memo ry? A study of three species with contrasting life history strategies. PLoS One 7(11):e494 71. https://doi.org/10.1371/journal.pone.0049471

Marchante H, Freitas H, Hoffmann JH (2011) The potential role of seed banks in the recover $\mathrm{y}$ of dune ecosystems after removal of invasive plant species. Appl Veg Sci 14(1):107-11 9. https://doi.org/10.1111/j.1654-109X.2010.01099.x

Margherita G, Petr P, Osborne BA (2016) Timing is everything: does early and late germinati 
on favor invasions by herbaceous alien plants?. J Plant Ecol (1):rtw105. https://doi.org/10. 1093/jpe/rtw105

Mason TJ, French K, Russell KG (2007) Moderate impacts of plant invasion and managemen $\mathrm{t}$ regimes in coastal hind dune seed banks. Biol Conserv 134(3):428-439. https://doi.org/1 0.1016/j.biocon.2006.08.032

Milakovic, Karrer (2016) The influence of mowing regime on the soil seed bank of the invas ive plant Ambrosia artemisiifolia L. Neobiota 28:39-49. https://doi.org/10.3897/neobiota.28. $\underline{6838}$

Montagnani C, Gentili R, Smith M et al (2017) The worldwide spread, success, and impact o f ragweed (Ambrosia spp.).Crit Rev Plant Sci 36(3):139-178. https://doi.org/10.1080/07352 $\underline{689.2017 .1360112}$

Nguyen TLT, Bajwa AA, Navie SC et al (2017) The soil seedbank of pasture communities in central Queensland invaded by Parthenium hysterophorus L. Rangeland Ecol Manag 70 (2):244-254. https://doi.org/10.1016/j.rama.2016.07.010

Nsikani MM, Geerts S, Ruwanza S et al (2020) Secondary invasion and weedy native species dominance after clearing invasive alien plants in South Africa: Status quo and prognosis. S Afr J Bot 132:338-345. https://doi.org/10.1016/j.sajb.2020.05.009

O'Loughlin LS, Green PT (2017) Secondary invasion: When invasion success is contingent on other invaders altering the properties of recipient ecosystems. Ecol Evol 7(19):7628-7637. https://doi.org/10.1002/ece3.3315

Olson LJ (2006) The economics of terrestrial invasive species: a review of the literature. Agr icultural and Resource Economics Review 35(1):178-194. https://doi.org/10.1017/S1068280 $\underline{500010145}$

Page ER, Nurse RE (2015) Cropping systems and the prevalence of giant ragweed (Ambrosia trifida): From the 1950's to present. Field Crop Res 184:104-111. https://doi.org/10.1016/ j.fcr.2015.09.013

Passos I, Marchante H, Pinho R et al (2017) What we don't seed: the role of long-lived see $\mathrm{d}$ banks as hidden legacies of invasive plants. Plant Ecol 218(11):1313-1324. https://doi.or $\mathrm{g} / 10.1007 / \mathrm{s} 11258-017-0770-6$

Pyšek P, Jarošík V, Hulme PE et al (2012) A global assessment of invasive plant impacts on resident species, communities and ecosystems: the interaction of impact measures, invadi ng species' traits and environment. Global Change Biol 18(5):1725-1737. https://doi.org/10. $\underline{1111 / \mathrm{j} .1365-2486.2011 .02636 . \mathrm{x}}$

Regnier EE, Harrison SK, Loux MM et al (2016) Certified crop advisors' perceptions of gian $\mathrm{t}$ ragweed (Ambrosia trifida) distribution, herbicide resistance, and management in the Co rn Belt. Weed Sci 64(2):361-377. https://doi.org/10.1614/WS-D-15-00116.1

Robertson SG, Hickman KR (2012) Aboveground plant community and seed bank compositio $\mathrm{n}$ along an invasion gradient. Plant Ecol 213(9):1461-1475. https://doi.org/10.1007/s11258012-0104-7

Schaffner U, Steinbach S, Sun Y et al (2020) Biological weed control to relieve millions fro m Ambrosia allergies in Europe. Nat Commun 11(1):1-7. https://doi.org/10.1038/s41467-02 $\underline{0-15586-1}$

Skálová H, Moravcová L, Čuda J et al (2019) Seed-bank dynamics of native and invasive Im patiens species during a five-year field experiment under various environmental conditions. 
NeoBiota 50:75-95. https://doi.org/10.3897/neobiota.50.34827

Strydom M, Veldtman R, Ngwenya MZ et al (2017) Invasive Australian Acacia seed banks: Size and relationship with stem diameter in the presence of gall-forming biological contr ol agents. PloS one 12(8):e0181763. https://doi.org/10.1371/journal.pone.0181763

Van Horn CR, Moretti ML, Robertson RR et al (2018) Glyphosate resistance in Ambrosia trif ida: Part 1. Novel rapid cell death response to glyphosate. Pest Manag Sci 74(5):1071-10 78. https://doi.org/10.1002/ps.4567

Vilà M, Espinar JL, Hejda M et al (2011) Ecological impacts of invasive alien plants: a met a-analysis of their effects on species, communities and ecosystems. Ecol Lett 14(7):702-7 08. https://doi.org/10.1111/j.1461-0248.2011.01628.x

Vilà M, Hulme PE (2017) Impact of Biological Invasions on Ecosystem Services. Springer, S witzerland. https://doi.org/10.1007/978-3-319-45121-3

Vink JP, Soltani N, Robinson DE et al (2012) Glyphosate-resistant giant ragweed (Ambrosia $t$ rifida) control in dicamba-tolerant soybean. Weed Technol 26(3):422-428. https://doi.org/10. 1614/WT-D-11-00184.1 
Figures

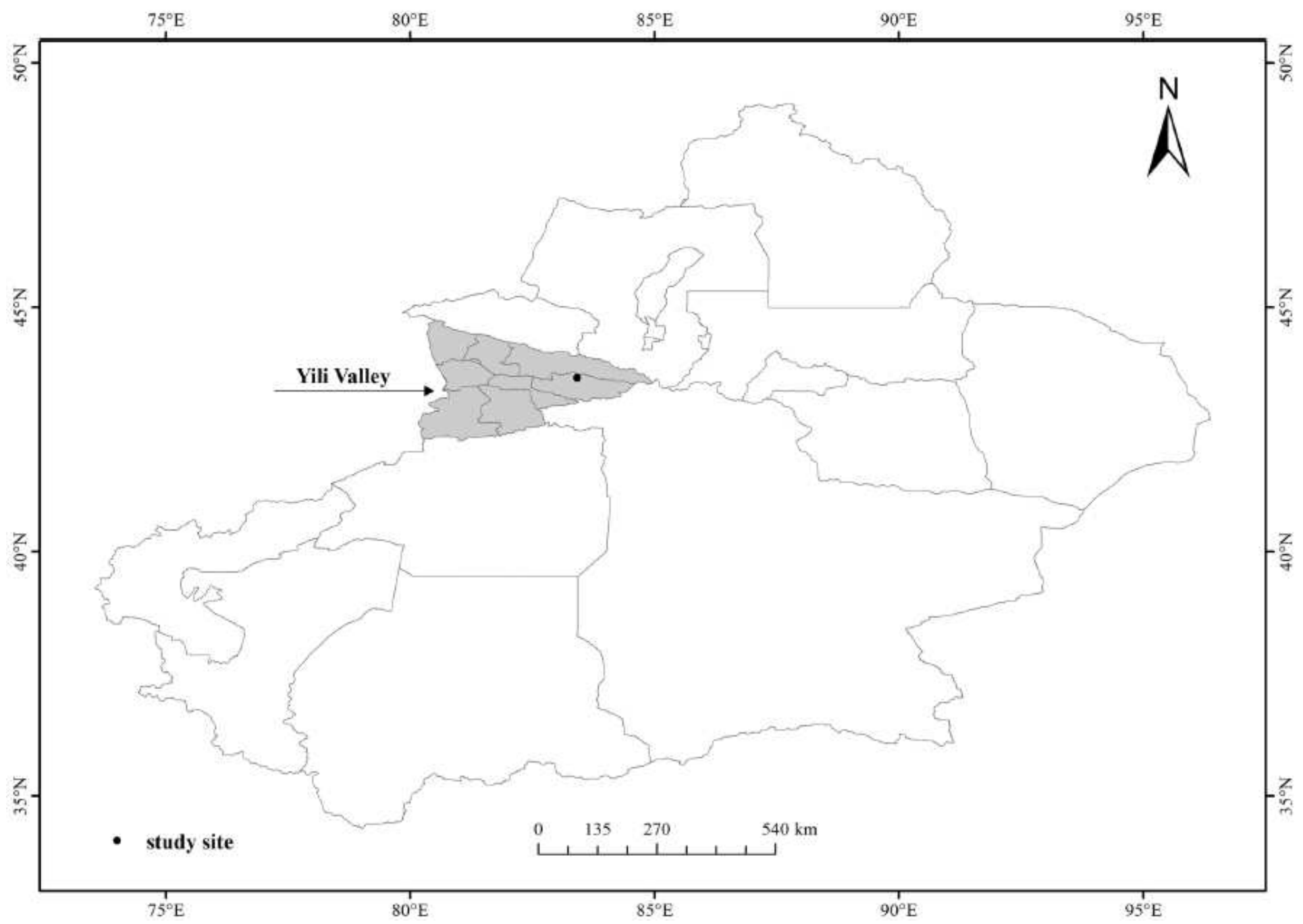

Figure 1

Study area within Yili Valley, Xinjiang, China Note: The designations employed and the presentation of the material on this map do not imply the expression of any opinion whatsoever on the part of Research Square concerning the legal status of any country, territory, city or area or of its authorities, or concerning the delimitation of its frontiers or boundaries. This map has been provided by the authors.
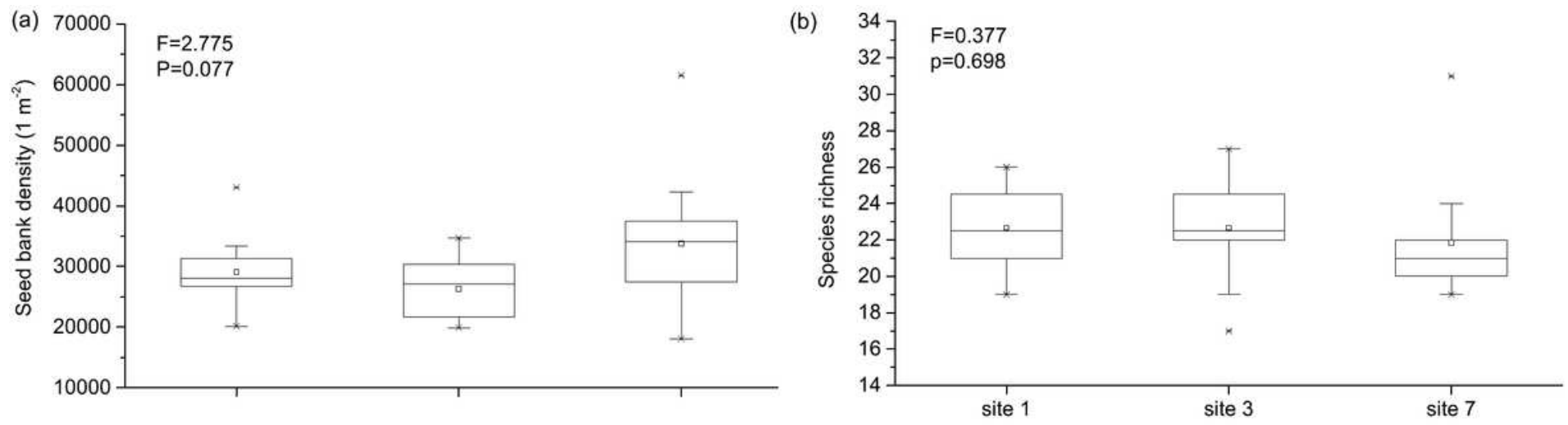
Figure 2

The distribution characteristics of (a) seed bank density and (b) species richness in noninvaded area are represented by box chart

(a)
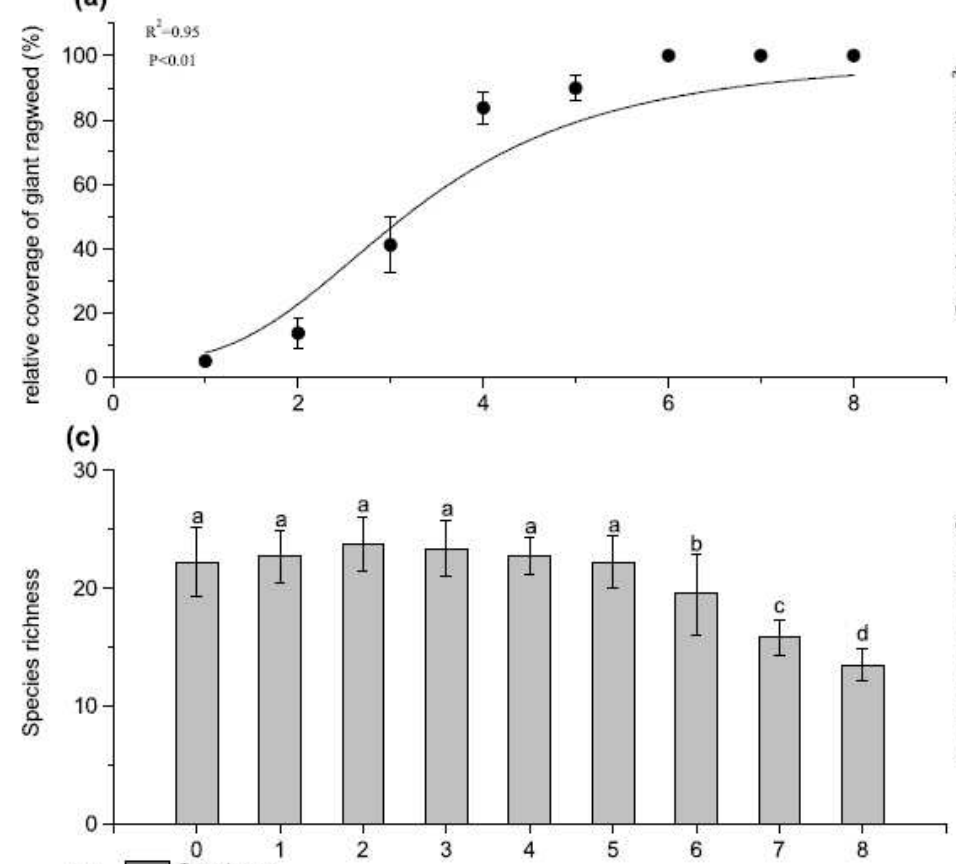

(e) $\square_{\text {Gramineae }}^{1}$

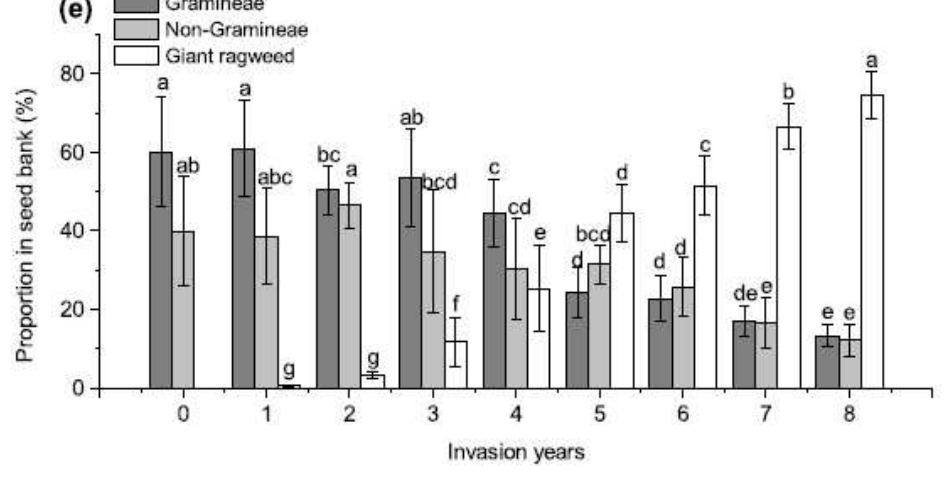

(b)
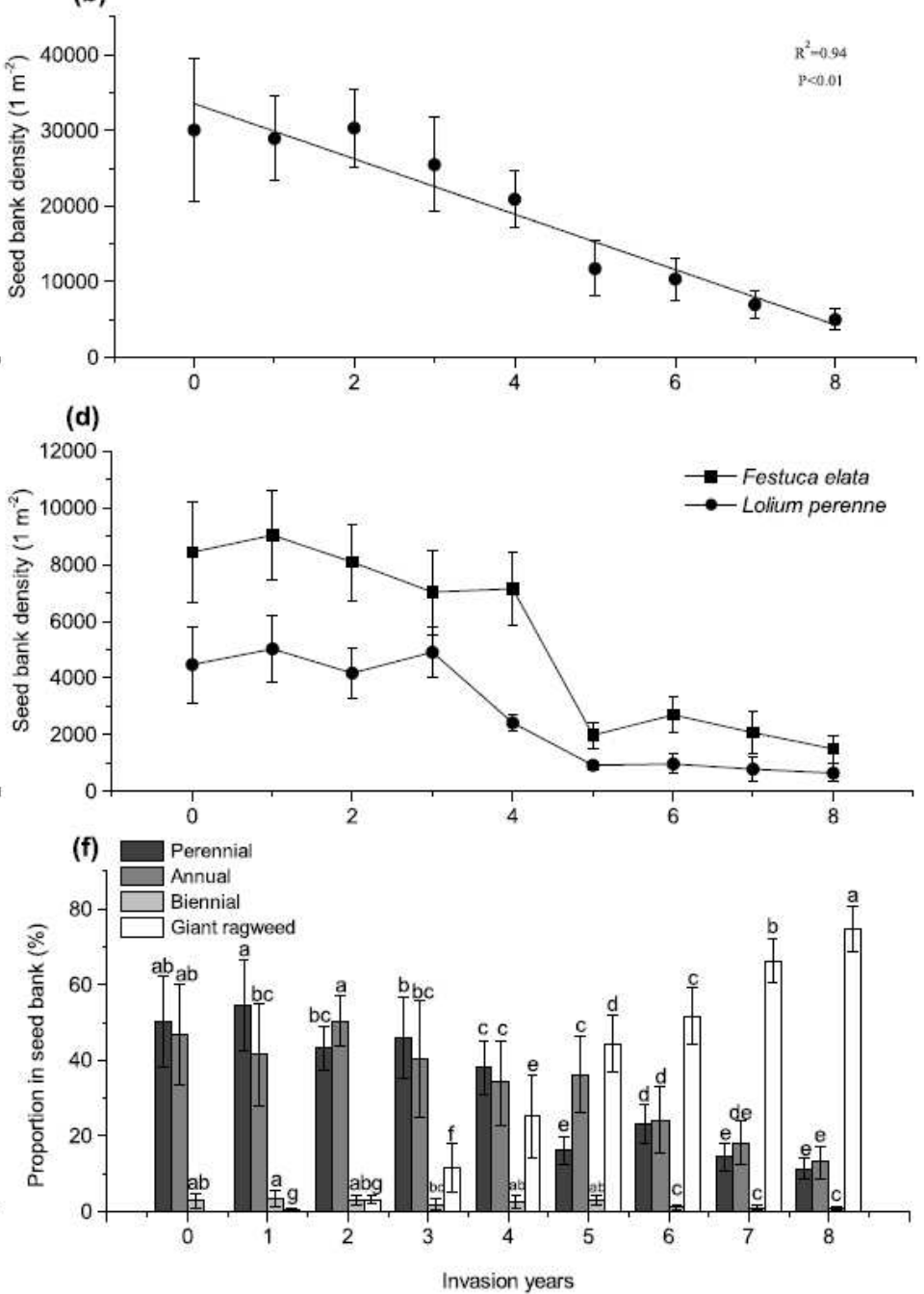

Figure 3

Effects of giant ragweed invasion duration on aboveground relative coverage and underground seed bank of native community. (a) the changes of relative coverage of giant ragweed with invasion time; the changes of (b) seed bank density and (c) species richness of native communities; and the changes of seed bank density with invasion time of (d) two dominant species and (e) gramineae/non-gramineae (f) and that species with different life cycles. Different letters indicate significant differences $(p<0.05)$ using a least significant difference test 

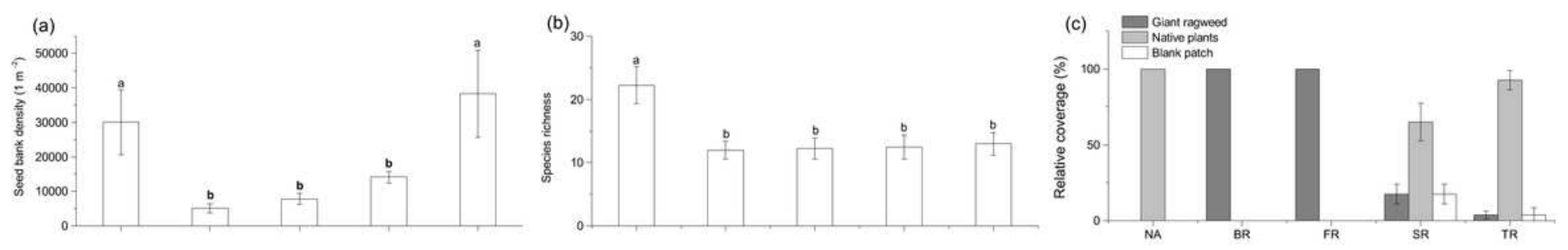

\section{Figure 4}

The restoration of (a) native seed bank density, (b) species richness in the seed bank and (c) native community coverage after removal of giant ragweed. Different acronyms represent different restoration times that NA (Noninvaded area), BR (Before restoration), FR (The first year of restoration), SR (The second year of restoration), TR (The third year of restoration). Different letters indicate significant differences $(p<0.05)$ using a least significant difference test 